九州大学学術情報リポジトリ

Kyushu University Institutional Repository

\title{
Radial Variation in the R_s-l in the SPAC of Several Tree Species
}

Ikeda, Takefumi

Department of Forestry, Faculty of Agriculture, Kyushu University

Suzaki, Tamio

Department of Forestry, Faculty of Agriculture, Kyushu University

https://doi.org/10.5109/23862

出版情報 : 九州大学大学院農学研究院紀要. 32 (1/2), pp.1-7, 1987-12. Kyushu University バージョン：

権利関係 : 


\title{
Radial Variation in the $\boldsymbol{R}_{s-l}$ in the SPAC of Several Tree Species
}

\author{
Takefumi Ikeda* and Tamio Suzaki \\ Department of Forestry, Faculty of Agriculture, \\ Kyushu University, Fukuoka 812
}

(Received February 23, 1987)

\begin{abstract}
To estimate the radial variation of axial conductance in the SPAC, diurnal trends in the sap flow velocity at the different depths in stem xylem and the xylem pressure potential were measured for three coniferous tree species and three broad-leaved tree species. Except for ring-porous wood species, the sap flow velocity increased with proximity to the cambial zone except in close proximity for coniferous and broad-leaved tree species. In the ring-porous wood species, the sap flow velocity in the earlywood vessels was larger than that in the latewood vessels. The sap flow velocity in the earlywood vessels of the current year's growth ring was larger than in those of 1-year-old growth ring. The resistance to water flow at various depths in stem xylem of the SPAC could be estimated from a relationship between xylem pressure potential and heat pulse velocity. The resistance in the latewood vessels of Q. acutissima was about 4 to 7 times as large as that in the earlywood vessels. It can be estimated that the earlywood vessels will play an important role in water conduction of ring-porous wood species.
\end{abstract}

\section{INTRODUCTION}

One of the most remarkable characteristics in tree development is secondary growth. Trees accumulate xylem every year as a result of repetition in secondary growth. This means an accumulation of water conducting tissues. Xylem is composed of heartwood and sapwood. The water conduction only occurs in sapwood but not in heartwood (Zimmermann, 1971). Even in sapwood the area of water conduction is different between species (Chaney and Kozlowski, 1977 ; Ikeda and Suzaki, 1981).

There have been many studies on sap flow velocity by means of the heat pulse velocity technique for estimating the rate of transpiration from the crown and the volumetric sap flow (Lassoie et al., 1977 ; Morikawa, 1974 ; Swanson, 1967 ; Swanson et al., 1979 ; Yamamoto and Watabe, 1980 ; Cohen et al., 1985). No studies have been dealt with sap flow from the standpoint of hydraulic conductance in trees in the SPAC (soil-plant-atmosphere-continuum). It is important to distinguish the difference in water conducting ability at different depths in xylem from stem surface for estimating water movement in the SPAC. It is difficult to estimate hydraulic conductance at various radial depths in the SPAC. In this study, the heat pulse velocity technique was used for estimating the diurnal trends in sap flow at different depths in stem xylem for

* Present address: Kyushu Br., For. and Forest Prod. Res. Inst., Kumamoto 860 
several tree species. Resistance to water flow at different depths in the SPAC was also estimated from the relationship between sap flow and xylem pressure potential.

\section{MATERIALS AND METHODS}

Six species growing at the nursery in Kyushu University, Fukuoka were used for this study. The attributes of the sample trees are listed in Table 1.

Table 1. Attributes of sample trees and depths of the heaters and the thermisters in stems.

\begin{tabular}{|c|c|c|c|c|}
\hline Species & $\begin{array}{l}\text { age } \\
\text { (yr) }\end{array}$ & $\begin{array}{l}\text { height } \\
\text { (m) }\end{array}$ & $\begin{array}{l}\text { dbh" } \\
(\mathrm{cm})\end{array}$ & $\begin{array}{c}\text { depth** } \\
(\mathrm{mm})\end{array}$ \\
\hline \multicolumn{5}{|l|}{ Coniferous trees } \\
\hline Crypromeria japonica & 10 & 5.50 & 8.5 & $11(1), 14(2), 19(3)$ \\
\hline Chamaecyparis obtusa & 10 & 5.15 & 6.8 & $11.5(1), 17(2)$ \\
\hline Pinus thunbergii & 9 & 5.15 & 7.8 & $8(1), 12.5(2), 18(3)$ \\
\hline \multicolumn{5}{|l|}{ Broad-leaved trees } \\
\hline Ring-porous wood & & & & \\
\hline Quercus acutissima & 9 & 5.23 & 7.5 & $8(1), 10(2), 15(3), 21(4)$ \\
\hline Radial-porous wood & & & & \\
\hline $\begin{array}{c}\text { Quercus glauca } \\
\text { Diffuse-porous wood }\end{array}$ & 9 & 4.35 & 4.7 & $6(1), 8 \quad(2), 12(3)$ \\
\hline Michelia compressa & 9 & 6.63 & 5.5 & $7(1), 11.5(2)$ \\
\hline
\end{tabular}

$*$ : diameter at breast height

**: Depths of the heaters and the thermisters in stems.

Numbers in parentheses correspond to those shown in Fig. 1 and Table 2.

To estimate the diurnal trends in water status and sap flow in trees, the xylem pressure potential $(\mathrm{P})$ of leaves was measured using a pressure chamber (PMS Instrument Co.). The sap flow velocity of the stems was measured by the heat pulse technique using an automatic multichannel sap flow meter (Yahata, 1984). Implanting holes were drilled by hand with a $2 \mathrm{~mm}$ bit. The heating element and thermisters for each sample tree were embedded at various depths from the bark surface into the stem xylem as shown in Table 1. Measurements of the heat pulse velocity and the xylem pressure potential were made during the early autumn.

After taking measurements of the heat pulse velocity and the xylem pressure potential, the sample trees were cut down. Stem segments including the segments with embedded element sets were sampled from the cut trees and divided into several pieces. The element set is composed of one heater and two thermisters. Each piece after cutting down was immediately fixed with FAA (Formalin acetic acid-alcohol). The fixed pieces were washed with tap water. The pieces embedded with the element

Fig. 1. Diurnal trends of heat pulse velocity and xylem pressure potential. Number in each figure correspond with those shown in Table 1 and 2, which mean depth in $\mathrm{mm}$ of the heater and the thermisters in stem xylem. A, Quercus acutissimu ; B, Quercus glauca ; C, Michelia compressa ; D, Cryptomeria japonica, E, Chamaecypris obtusa; F, Pinus thunbergii. T, Temperature ; VPD, Vapour pressure deficit ; HPV, Heat pulse velocity ; $\mathrm{P}$, Xylem pressure potential. 
Radial Variation in $R_{s}$,
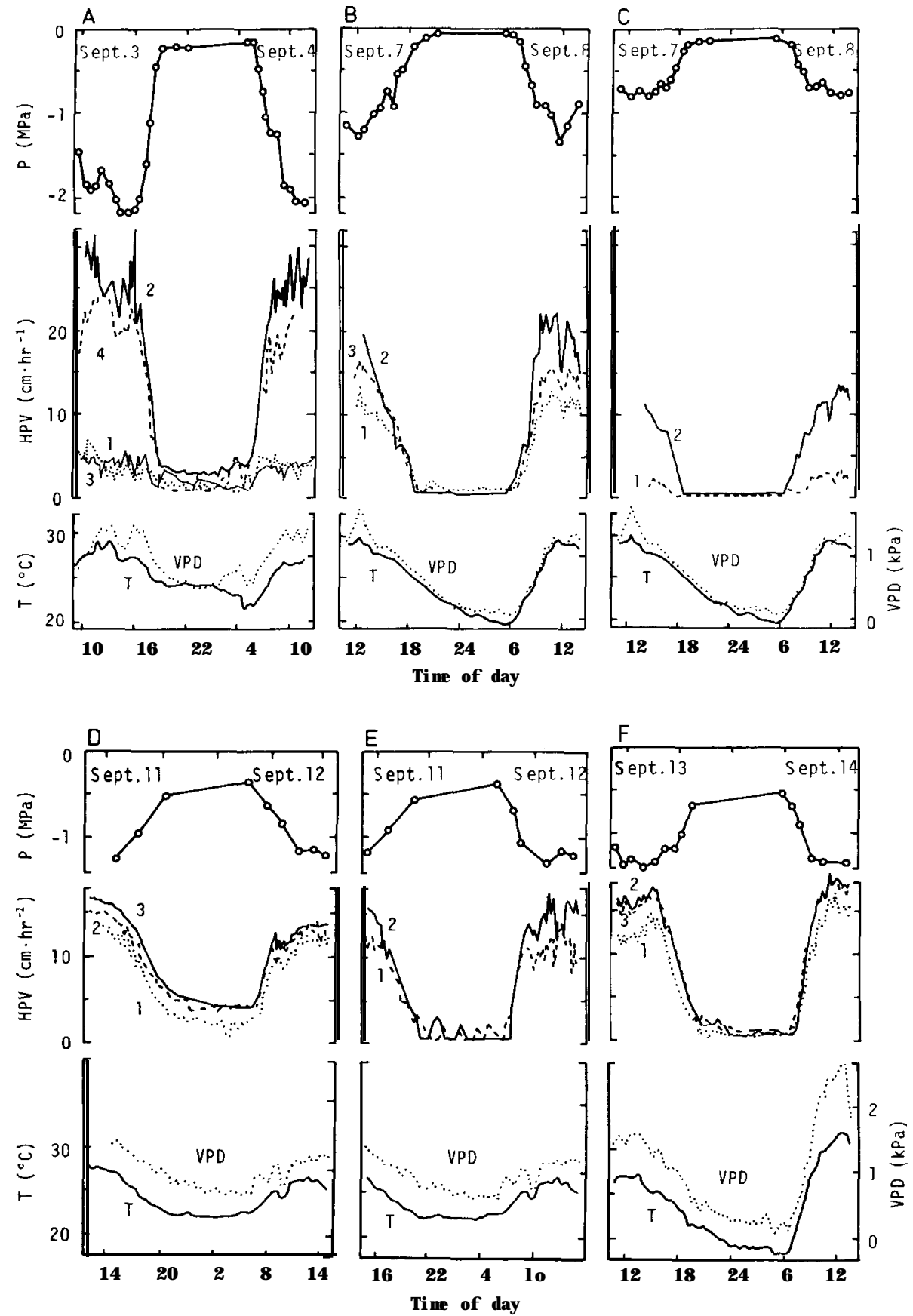
sets were split longitudinally and then distance between the heater and the thermisters were measured.

The heater and thermisters were embedded on the southward of stem. The element sets embedded paralleled mutually at intervals of $1 \mathrm{~cm}$, so that the effect of heat from the heater unit was excluded (Lassoie et al., 1984).

The water conducting tissues in the vicinity of the area with embedded element sets were examined anatomically using a scanning electron microscope (JEOL Ltd.) according to the procedure described by Ikeda and Suzaki (1984).

\section{RESULTS}

Differences in heat pulse velocities at various depths in stem xylem of all species were observed (Fig. 1).

In five species, which included three coniferous tree species and two broad-leaved tree species but excluding Q. acutissima, the difference in heat pulse velocity at different depths in stem xylem was small (Fig. 1, B-F). The larger heat pulse velocities were observed in the range of about $1 \mathrm{~cm}$ to $2 \mathrm{~cm}$ from the bark surface.

In Q. acutissima, which is a ring-porous wood species, two distinctly different diurnal trends in heat pulse velocity were observed (Fig. 1, A). During the daytime one showed a large heat pulse velocity the other showed a small heat pulse velocity. As a result of anatomical study the former was detected at the earlywood vessels and the latter at the latewood vessels. The heat pulse velocity was larger in the current year' $\mathrm{s}$ growth ring than in the 1-year-old growth ring.

In Q. acutissima the heat pulse velocity of about $31 \mathrm{~cm} \cdot \mathrm{hr}^{-1}$ was largest, and xylem pressure potential of $-2.2 \mathrm{MPa}$ was smallest, while in other species they were about $15 \mathrm{~cm} \cdot \mathrm{hr}^{-1}$ to $20 \mathrm{~cm} \cdot \mathrm{hr}^{-1}$ and $-0.9 \mathrm{MPa}$ to $-1.5 \mathrm{MPa}$, respectively.

Heat pulse velocities at different depths in stem xylem from the bark surface can be transformed by the resistence to transpirational flux using the following procedures.

Assuming that the pathway for water movement in a tree is a bundle of capillary vessels from the roots to the leaves, the water in soil can be transpired from the leaf surface to the air by way of the capillary vessels. During movement of water through each capillary the resistance to water flow will occur.

Elfving et al. (1972) showed a water flux model in trees using an analogy of Ohm' $\mathrm{s}$ law and Fick's law as follows :

$$
\Psi_{l}=\Psi_{s}-R_{s-l} \times V P D / R_{t}
$$

where $\Psi_{\iota}$ and $\Psi_{s}$ are the leaf and soil water potentials, $R_{s-\iota}$ is the total resistance to water flow from soil to leaves, VPD is the vapour pressure deficit of air and $R_{\iota}$ is the leaf resistance. form :

Thompson and Hinckley (1977) have modified equation (1) using the following

$$
P=B P-R_{s-l} \times V P D / R_{l}
$$

where $P$ is the xylem pressure potential, and $B P$ is $P$ measured just before sunrise.

To use equation (2) for estimating resistance to water flow at different depths in 
xylem, following certain assumptions were made. Firstly, heat pulse velocity (HPV) is substituted for $V P D / R_{l}$ and can be used as transpirational flux at different depths in xylem. Equation (2) is then modified to equation (3).

$$
P=B P-R_{s-\iota} \times H P V
$$

Secondly, resistance to transpirational flux is arranged in parallele into xylem. Thirdly, the xylem pressure potential gradient at each point in xylem, at which heat pulse velocity was measured, is equal to all measured points. Based on the mentioned assumptions, resistance to water flow from the roots to the leaves by way of various depths in stem xylem in the SPAC were estimated by equation (3). The estimated values of resistance can be used for relatively indicating a radial variation in $R^{\mathrm{s}-i}$ in the SPAC of a sample tree.

The values of the $H P V$ and $P$ in Fig. 1 were read at half-hourly intervals and then the values of $R_{s-\iota}$ shown in Table 2 were estimated from equation (3). Except for Q. acutissima, the resistance in the five species were smallest at position 2 , and were large at position 1 which is near the cambial zone. On the other hand, the difference in resistance in Q. acutissima was very large and resistance at position 3 was 6.6 times as large as that at position 2 .

Table 2. $\mathbf{R}_{\mathbf{s}-1}$ for each depth in stems of several tree species.

\begin{tabular}{ccccc}
\hline \multirow{2}{*}{ Species } & \multicolumn{4}{c}{$\mathrm{R}_{\mathrm{s}-1}\left(\mathrm{MPa} \cdot \mathrm{cm}^{-1} \cdot \mathrm{hr}\right)$} \\
\cline { 2 - 5 } & 1 & \multicolumn{2}{c}{ position in stems* } & \\
\cline { 2 - 5 } & & & 3 & 4 \\
\hline Coniferous trees & & & \\
Cryptomeria japonica & $\mathbf{0 . 9 3}$ & $\mathbf{0 . 8 8}$ & 0.86 & \\
Chamaecyparis obtusa & $\mathbf{0 . 7 4}$ & $\mathbf{0 . 5 6}$ & $\mathbf{0 . 4 7}$ & \\
Pinus thunbergii & $\mathbf{0 . 5 4}$ & $\mathbf{0 . 4 4}$ & $\mathbf{0 . 8 7 \prime \prime}$ \\
Broad-leaved trees & & & $\mathbf{5 . 1 7}$ & \\
Quercus acutissima & $\mathbf{3 . 7 8 ^ { \prime }}$ & $\mathbf{0 . 7 8}$ & $\mathbf{0 . 7 5}$ & \\
Quercus glauca & $\mathbf{0 . 9 8}$ & $\mathbf{0 . 5 3}$ & & \\
Michelia compressa & $\mathbf{2 . 1 8}$ & $\mathbf{0 . 5 4}$ & & \\
\hline
\end{tabular}

* : numbers for each species correspond to those shown in Fig. 1

1 :latewood vessel

e: earlywood vessel

In anatomical studies on water conducting tissues, larger values of heat pulse velocities of Q. acutissima were obtained in the earlywood vessels and the slower values of heat pulse velocitiese were in the latewood vessels. Development of tyloses was partly observed in the earlywood vessels of the l-year-old growth ring of $\mathrm{Q}$. acutissima.

In Q. acutissima, tyloses were observed in a part of the vessels surrounding holes from the inserted element sets (Fig. 2-A). In other species, this was not observed. Further, in Q. glauca the primary walls of vessels near the cambial zone were still present at the pore site (Fig. 2-B) and in coniferous tree bordered pit near the cambial zone were imperforated and immature. 

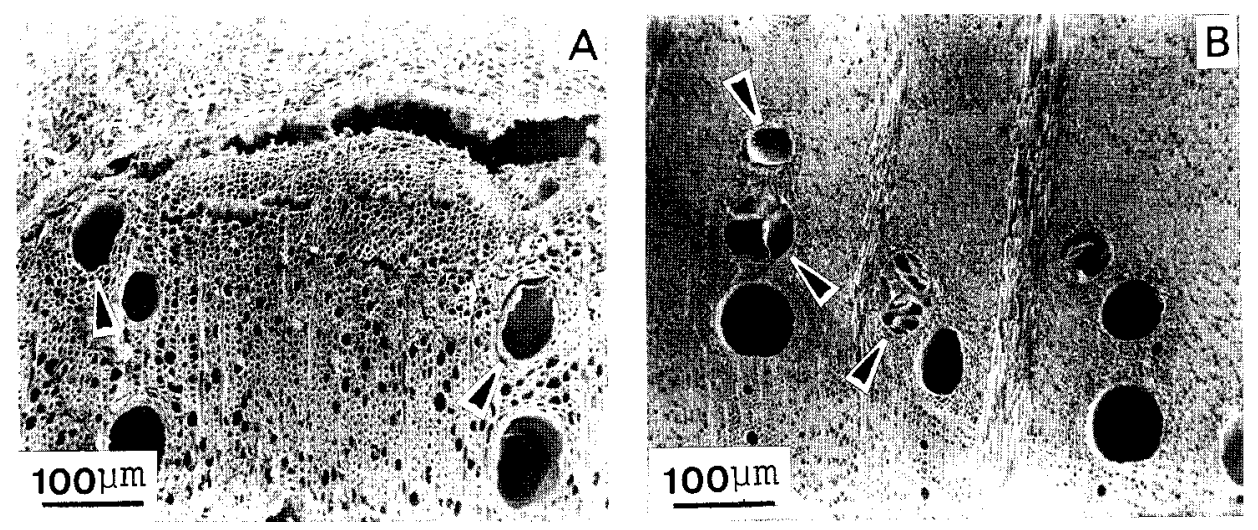

Fig. 2. A, Tyloses (arrows) developed in vessels surround holes in which thermisters and heater were inserted in $Q$. acutissima. B, Vessels of Q. glauca. Arrows show that the primary wall is still presented at the pore site.

\section{DISCUSSION}

Water conduction in a ring-porous species takes place primarily through the large earlywood vessels in the current year's growth ring (Zimmermann, 1971). This was quantitatively confirmed by the radial variation of the heat pulse velocities and the resistances to water flow, which were estimated from the relationship between the heat pulse velocity and the xylem pressure potential.

Larger heat pulse velocities in the large earlywood vessels of the current year's growth ring than in those of the 1-year-old growth ring are due to partial blockage of the vessel lumens of the 1-year-old growth ring with tyloses. Small heat pulse velocities near the cambial zone were observed in five tree species except Q. acutissima. This has been also reported in many other species, which are Douglas-fir (Lassoie et al., 1977 ; Cohen et al., 1985), lodgepole pine, Englemann spruce (Mark and Crew, 1973), Mountain beech (Swanson et al., 1979), and pear tree (Yamamoto and Watabe, 1980). This is because in hardwood species the primary walls are still present at the pore site and in coniferous species the matrix substances of margo are not removed and therefore water can not move through the vessels and the tracheids.

In Q. acutissima tyloses observed in vessel lumens surrouding holes into which elements are inserted even in the current year's growth ring appear to be traumatic tyloses as observed in Q. serrata (Shibata et al., 1981, 1982). Development of tyloses in the vessel lumens restricts the upward flow of water (Zimmermann, 1971). If continuous measurement of heat pulse velocity in ringporous species as Q. acutissima were taken, heat pulse velocities must be underestimated in comparison with the real heat pulse velocity because of blockage of vessel lumens with tyloses.

Radial variation in the axial resistance to water flow in stem xylem in the SPAC estimated from the relationship between the heat pulse velocity and the xylem pressure potential showed that the resistance was large near the cambial zone, small at a short distance from cambial zone and also large at inner positions. Edwards and Booker (1984) reported that the axial hydraulic conductivity of Populus deltoides and Populus 
yunnanensis, which are diffuse-porous species, are largest in the second growth ring. There are radial variations in axial conductance in xylem. The radial variation is related closely to the anatomy of water conducting tissues.

\section{REFERENCES}

Chaney, W. A. and T. T. Kozlowski 1977 Patterns of water movement in intact and excised stems of Fraxinus americana and Acer saccharum seedlings. Ann. Bot., 41: 1093-1100

Cohen, Y., F. M. Kelliher and T. A. Black 1985 Determination of sap flow in Douglas-fir trees using the heat pulse technique. Can. J. For. Res., 15: 422-428

Edwards, E. R. and R. E. Booker 1984 Radial variation in the axial conductivity of Populus and its significance in heat pulse velocity measurement. J.Exp. Bot., $35: 551-561$

Elfving, D. C., M. R. Kaufmann and A. E. Hall 1972 Interpreting leaf water potential measurements with a model of the soil-plant-atmosphere continuum. Physiol. Plant., 27: 161-168

Ikeda, T. and T. Suzaki 1981 Studies on hydraulic conductance in trees (II) Resistance to water flow in excised stems. Bull. Kyushu Br. Jpn. For. Soc., 34: 119-120 (in Japanese)

Ikeda, T. and T. Suzaki 1984 Influence of pine-wood nematodes on hydraulic conductivity and water status in Pinus thunbergii. J. Jpn. For. Soc., 66: 412-420

Lassoie, J. P., D. R. M. Scott and L. J. Fritschen 1977 Transpiration studies in Douglsa-fir using the heat pulse technique. Forest Sci., $23: 377-390$

Mark, W. R. and D. L. Crews 1973 Heat-pulse velocity and bordered pit conduction in living Engelmann spruce and lodgepole pine trees. Forest Sci., 19: 291-296

Morikawa, Y. 1974 Sap flow in Chamaecyparis obtusa in relation to water economy of woody plants. Bull. Tokyo Univ. For., 66: 251-297 (in Japanese with English summary)

Shibata, K., H. Harada and H. Saiki 1981 Development and structure of traumatic tyloses in Quercus serrata Thunb. I. Development of traumatic tyloses in various boring seasons. Mokuzai Gakkaishi, 27 : 618-625 (in Japanese with English summary)

Shibata, K., H. Harada and H. Saiki 1982 Development and structure of traumatic tyloses in Quercus serrata Thunb. II. Developing precess of the traumatic tyloses wall. Mokuzai Gakkaishi, $28: 1-9$ (in Japanese with English summary)

Swanson, R. H. 1967 Seasonal cource of transpiration of lodgepole pine and Engelmann spruce. In "Forest hydrology" eds. by W. E. Sopper and H. W. Lull, Pergamon Press, New York, pp. 419-434

Swanson, R. H., U. Benecke and W. M. Havranek 1979 Transpiration in mountain beech estimated simultaneously by heat-pulse velocity and climatised cuvette. New Zealand J. For. Sci., $9: 170$ $-176$

Thompson, D. R. and T. M. Hinckley 1977 A simulation of water relations of white oak based on soil moisture and atmosphere evaporation demand. Can. J.For, Res., $7:$ 400-409

Yahata, T. 1984 An automatic multichannel recording system for the heat pulse velocity technique. J. Jpn. For. Soc., 66: 241-246 (in Japanese)

Yamamoto, T. and S. Watabe 1980 Measurements of sap velocities in stems, peduncles and petioles of pear trees by a heat pulse method, J. Jpn. Soc. Hort. Sci., 49 :311-325 (in Japanese with English summary)

Zimmermann, M. H. 1971 Transport in the xylem. In "Trees structure and function" eds. by M. H. Zimmermann and C. L. Brown, Springer-Verlag, Berlin, pp. 169-220 